\title{
Optimization of Retention Time of Microbial Community Structure of Activated Sludge Process
}

\author{
M P. Shah* \\ Industrial Waste Water Research Laboratory Division of Applied \& Environmental Microbiology Enviro Technology Limited Gujarat, \\ India \\ *Corresponding author: shahmp@uniphos.com
}

Received December 02, 2014; Revised December 11, 2014; Accepted December 17, 2014

\begin{abstract}
Ammonia Oxidizing Bacteria community composition was analysed using fluorescence in situ hybridization (FISH) and denaturing gradient gel electrophoresis (DGGE), and the identified populations were enumerated by quantitative FISH. Potential nitrification rates were determined in batch tests and the in situ rates were calculated from mass balances of nitrogen in the plants. Increased SRT did not reduce the nitrification activity, but the number per mixed liquor suspended solids nor was community composition of AOB affected. Two dominant AOB populations related to Nitrosomonas europaea and Nitrosomonas oligotropha were identified by FISH, whereas only the latter could be detected by DGGE. The effect of a longer SRT on the activity was probably because of physiological changes in the AOB community rather than a change in community composition.
\end{abstract}

Keywords: activated sludge, ammonia-oxidizing bacteria, denaturing gradient gel electrophoresis, fluorescence in situ hybridization, nitrification, nitrogen removal, solids retention time

Cite This Article: M P. Shah, "Optimization of Retention Time of Microbial Community Structure of Activated Sludge Process.” American Journal of Water Resources, vol. 2, no. 6 (2014): 149-158. doi: 10.12691/ajwr-2-6-3.

\section{Introduction}

The growth of the world population, the development of various industries, and the use of fertilizers and pesticides in modern agriculture have overloaded not only the water resources but also the atmosphere and the soil with pollutants (Shah et al., 2013). The degradation of the environment due to the discharge of polluting wastewater from industrial sources is a real problem in several countries. This situation is even worse in developing countries like India where little or no treatment is carried out before the discharge (Shah et al., 2013). Traditional biological nitrogen removal (BNR) is accomplished by a two-stage treatment, i.e. nitrification and denitrification. In the first stage, ammonia is oxidized to nitrite by ammonia oxidizing bacteria (AOB), and then to nitrate by nitrite oxidizing bacteria (NOB). Thereafter, nitrate is reduced to nitrite, and then to nitrogen gas (N2) in the second anoxic denitrification stage (Zhu et al., 2008). Nitrite is an intermediate in two stages. If ammonia is oxidized to nitrite (nitritation), and then directly reduced to N2 gas (denitritation), the process will be largely shortened. Compared with traditional BNR, aeration costs can be reduced by $25 \%$ and demand of carbon source is decreased by $40 \%$ in nitritation/denitritation (Sun et al., 2010). Previous studies found that several factors affecting the metabolic activity and growth rate of $\mathrm{AOB}$ and NOB, such as high free ammonia (FA) and free nitrous acid (FNA) concentration (Park et al., 2010), pH value (He et al., 2012), temperature (Tao et al., 2012), sludge retention time (SRT) (Hellinga et al., 1998), hydraulic retention time (HRT) (Zeng et al., 2010), dissolved oxygen (DO) (Blackburne et al., 2008; Guo et al., 2009) and inhibitor (Mosquera-Corral et al., 2005). Application of QPCR in nitritation/denitritation was mainly related to quantification of AOB (Wang et al., 2012; Yapsakli et al., 2011), and very limited studies regarding quantification of NOB. However, the key to achieve nitritation is to inhibit or eliminate NOB. The NOB washed out of system is usually demonstrated through a fact that nitrite accumulation ratio (NAR) reaches a high level (>80\%). Such indirect inference is not rigorous enough since it cannot distinguish between NOB inhibited and eliminated. The two situations will lead to different operational results. If the metabolic activity of NOB is just inhibited, nitritation will be unstable and even be destroyed when the conditions favour NOB growth. If NOB is washed out of system, nitritation will be stably performed and not be influenced by the short-term change of operational conditions. There is no report regarding the population dynamics of NOB during nitritation establishing. Due to lack of NOB detection in biological wastewater treatment, the correlation of community structure and population dynamics of NOB with operational conditions is not revealed. Therefore, the mechanism of nitritation cannot be clearly explained. The aim of this work was to survey the AOB communities in relation to nitrification during a 5-month period in two full-scale activated sludge processes, within the same treatment plant, with different SRTs and mixed liquor suspended solids (MLSS) 
concentrations. Both processes were operated with fairly long SRTs to ensure stable nitrification as the required aerobic SRT is more than $10 \mathrm{~d}$ in cold climates. Both the MLSS concentration and retention time could affect the activity, density, and composition of the biomass in the activated sludge. We assumed that the process with the shorter SRT should have a higher nitrification rate than a system with longer SRT. A change in nitrification rate would either depend on a difference in AOB numbers, AOB community composition or an increased cell-specific ammonia oxidation rate of the same populations. We used quantitative FISH to determine the numbers of $\mathrm{AOB}$ and to detect certain groups of $\mathrm{AOB}$ during the experimental period. A large set of probes targeting the 16S rRNAs of identified AOB groups were used with a nested approach. To our knowledge, FISH has not earlier been employed for surveys of AOB numbers other than for shorter periods. The AOB community composition determined by DGGE analysis of partial 16S rRNA genes (rDNA) was discussed in relation to that obtained by FISH.

\section{Materials \& Methods}

\subsection{Operation}

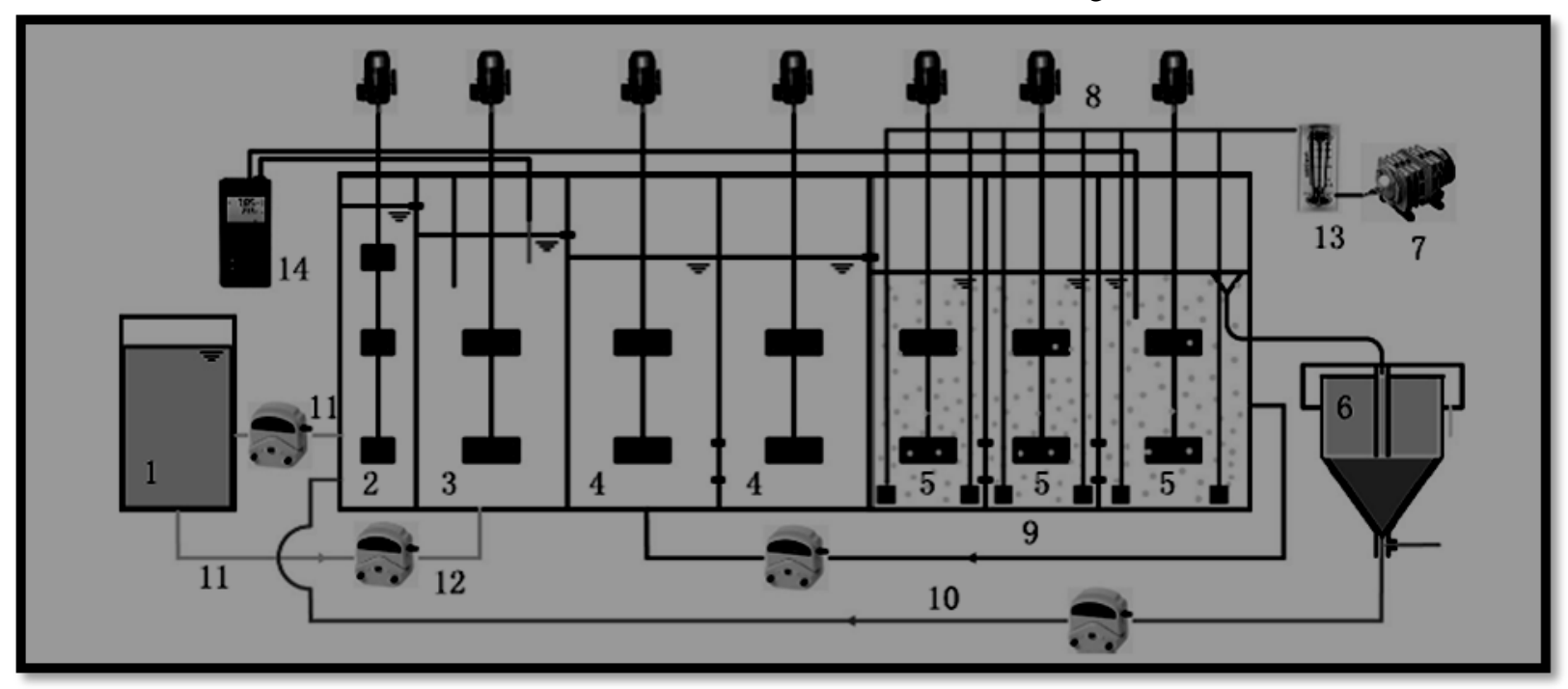

Figure 1 shows the experimental system consisting of a reactor with a working volume of $71 \mathrm{~L}$ and a secondary settler of $24 \mathrm{~L}$. The reactor was divided into seven chambers. The first chamber was a pre-anoxic zone for denitrification of returned sludge (external recycle, R1) from secondary settler and for one-third of influent. The second chamber provided an anaerobic zone for phosphorus release and for two-thirds of influent. Therefore, organic matter in raw wastewater could be used as the carbon sources for denitrification and phosphorus release. The third and fourth chambers were anoxic zones for denitrification of nitrite/nitrate recirculation (internal recycle, R2) from the last aerobic chamber. The last three chambers were aerobic zones for ammonia oxidation. The volume ratio of the pre-anoxic to anaerobic to anoxic to aerobic zone was 1.0:1.9:3.4:4.0. The flow rates of two feedings, returned sludge and nitrate recirculation were controlled by peristaltic pumps. Anaerobic zone was equipped with an ORP meter and each aerobic chamber was equipped with one DO probe. The air flow meter controlled the aeration rate to achieve the desired DO concentration. Temperature in the reactor was maintained at $25 \pm 1^{\circ} \mathrm{C}$ using a heater and thermostat. The sludge retention time (SRT) was controlled at 20 days by discharging an appropriate amount of settled sludge. The mixed liquor suspended solid (MLSS) concentration was about $3500 \pm 500 \mathrm{mg} / \mathrm{L}$.

Figure 1. Schematic diagram of process (1. raw wastewater tank; 2. pre-anoxic zone; 3. anaerobic zone; 4. anoxic zone; 5. aerobic zone; 6. settler; 7. air pump; 8. mixer; 9. internal recycle; 10. external recycle; 11. influent; 12. pump; 13. airflow meter; 14. DO and ORT meter)

\subsection{Sampling}

Table 1. Raw Waste Water Characteristics

\begin{tabular}{ccc}
\hline Contents & Range & Average \\
\hline COD (mg/L) & $84.6-267.6$ & 168.1 \\
NH4-N (mg/L) & $49.7-103.1$ & 71.8 \\
$\mathrm{NO}_{2}-\mathrm{N}(\mathrm{mg} / \mathrm{L})$ & $0-0.10$ & 0.01 \\
$\mathrm{NOJ}-\mathrm{N}(\mathrm{mg} / \mathrm{L})$ & $0.06-1.3$ & 0.57 \\
$\mathrm{TN}(\mathrm{mg} / \mathrm{L})$ & $49.7-103.4$ & 72.6 \\
$\mathrm{C} / \mathrm{N}$ & $0.86-3.38$ & 2.33 \\
$\mathrm{pH}$ & $7.13-7.42$ & 7.31 \\
\hline
\end{tabular}

The seed sludge was taken from a Industrial wastewater treatment plant with a typical anoxic-aerobic process. This plant performs traditional nitrification-denitrification without nitrite accumulating. Raw wastewater from a campus sewer line was pumped into a storing tank for sedimentation, and then fed into the reactor. The characteristics of raw wastewater are given in Table 1. The average influent COD to nitrogen ratio $(\mathrm{C} / \mathrm{N})$ was only about 2.33 , and thus the organic carbon source was typically limiting. For the DNA-based studies and the FISH analysis, $10-\mathrm{ml}$ portions of activated sludge was centrifuged for $10 \mathrm{~min}$ at $4500 \mathrm{~g}$. The supernatant was discarded and the pellet was stored at $-20^{\circ} \mathrm{C}$.

\subsection{Chemical Analysis}

In the influent and effluent water MLSS was analysed and total $\mathrm{N}, \mathrm{NH}_{4}{ }^{+}-\mathrm{N}, \mathrm{NO}_{3}{ }^{-}-\mathrm{N}$, and $\mathrm{COD}$ were determined by colorimetric methods, in 24-h composite samples during weekdays and 48-h composite samples during weekends. Grab samples from the effluent of the aerated basins were analysed for mixed liquor suspended solids 
(MLSS), MLVSS, and pH. On-line instruments also monitored temperature, $\mathrm{pH}$, and MLSS in the basins, as well as dissolved oxygen (DO) in zones 3-6 and $\mathrm{NH}_{4}{ }^{+}-\mathrm{N}$ in the effluent.

\subsection{Nitrification Rates}

The potential nitrification rate was estimated weekly in four replicate samples according to the method developed by Vandkvalitets institutet (Anon 1993). Briefly, $5 \mathrm{ml}$ sludge was incubated with $5 \mathrm{ml}$ of $17.8 \mathrm{mmol} \mathrm{l}^{-1}$ (NH4) ${ }_{2} \mathrm{SO}_{4}, 80 \mathrm{mmol} \mathrm{l}^{-1} \mathrm{NaHCO}_{3}$ and oxygen in excess at $20^{\circ} \mathrm{C}$ for $1 \mathrm{~h}$ on a rotary shaker. The production rate of $\mathrm{NO}_{3}{ }^{-}-\mathrm{N}+\mathrm{NO}_{2}{ }^{-}-\mathrm{N}$ was measured photometrically using flow injection analysis. MLSS and MLVSS concentrations were determined in all four subsamples. The actual nitrification rates in each experimental train at the WWTP were calculated through nitrogen mass-balances in the composite samples each sampling day. The measured flow, MLVSS, and influent and effluent total nitrogen and ammonium concentrations for each sampling day were used in the calculations. The average ammoniaassimilation values were assumed to be $2 \mathrm{mg} \mathrm{N} \mathrm{l}^{-1}$,

\subsection{FISH and Confocal Laser-scanning Microscopy}

As all samples were collected, centrifuged and frozen as pellets immediately after sampling, no fresh material was available for FISH. To check whether the frozen pellets could be used for FISH, a separate sample of fresh sludge was collected. One portion of the fresh sample was immediately fixed in 4\% par formaldehyde, and another portion was treated exactly like the samples in this study (i.e. centrifuged and frozen after the supernatant had been discarded). After $14 \mathrm{~d}$ incubation in the freezer, the frozen pellets were thawed and fixed as described below. The two differently treated samples were then hybridized with the probe EUB338, and co-stained with SYTO9 (n 1/4 7). Random pictures were collected and the relative abundance of EUB338 to SYTO9 was calculated for the two treatments (see below for details). As no significant difference (paired ttest, $\mathrm{P} 1 / 40.76$ ) between the frozen $(60.4 \pm 9.1 \%)$ and fresh samples $(58.1 \pm 14.5 \%)$ or any visible damage to the frozen cells could be noted in the microscope, FISH was applied to the frozen pellets in this study as described in the following. Frozen pellets of activated sludge were thawed and fixed in $4 \%$ para formaldehyde, washed with phosphate-buffered saline (PBS) and stored in PBS-ethanol (1:1) at) $20^{\circ} \mathrm{C}$ until further use. In situ hybridization with fluorescently labelled rRNA-targeted probes was performed at $46^{\circ} \mathrm{C}$ for $2 \mathrm{~h}$ as described by Manz et al. (1992). Target sequences, hybridization conditions, and references for the probes used in this study are listed in Table 2. All fluorescent probes and unlabelled competitor probes were obtained from Thermo Hybaid. Fluorescent probes were 5'-labelled with one of the sulfoindocyanine dyes indocarbocyanine (Cy3) or indodicarbocyanine (Cy5). After the hybridization, all samples were additionally stained for 10 min with a $1 \mu \mathrm{mol} \mathrm{^{-1 }}$ solution of the nucleic acid stain SYTO9. To prevent fluorochrome bleaching, all slides were mounted in Citifluor AF1. Confocal images of FISHand SYTO9-stained samples were collected with a BioRad Radiance 2000 MP microscope using the $\mathrm{Ar} \mathrm{Kr} / \mathrm{Ar}$
(488 nm), GHe/Ne (543 nm) and Red Diode (638 nm) lasers and the bundled software Laser Sharp 2000. Images for quantification were collected as 8-bit images of $512 \cdot 512$ pixels (resolution: 1.65 pixels $\mu \mathrm{m}^{-1}$ using a Nikon Plan Fluor 40\%1.40 oil objective and Kalman filtration $(n=3)$. Images for micrographs and calibration of cell sizes were collected as 8-bit images of $1024 \cdot 1024$ pixels (resolution: 4.97 pixels $\mu^{-1}$ using a Nikon Plan Apo 60/1.30 oil IR objective and Kalman filtration ( $\mathrm{n}=$ 7).

\subsection{Quantification of total Cell Bio Volume}

From each sample, a given volume of sludge $(5 \mu \mathrm{L}$ per well) was spotted onto microscope slides with wells ( 6 $\mathrm{mm}$ ), and care was taken to make sure that the sludge was evenly distributed in each well. The total bio volume of each sample was measured by randomly collecting 25 full z-stacks (step size $1 \mu \mathrm{m}$ ) in all SYTO9-stained samples. Five separately stained subsamples were analysed for each process and sampling date. The z-stacks were exported as a series of TIFF files, and analysed for bio volume $\left(\mu \mathrm{M}^{3}\right.$ $\mu \mathrm{M}^{-2}$ ) in MATLAB using the program COMSTAT (Heydorn et al. 2000). A graph of the accumulated mean was generated for each sample to make sure that the 25 stacks collected were enough to get a stabilized accumulative mean (with stabilized standard deviation) of the bio volume. In most cases 15-20 stacks would have been enough, but all 25 were collected. As the size of the well and the volume of sludge spotted onto each well were known, the bio volume in the original samples could then be calculated from the measured fluorescing bio volume.

\subsection{Quantification by FISH}

The signal of specific probes in each sample $(n=5)$ was measured by collecting the probe signal along with the SYTO9 signal in 50 microscope fields, randomly selected in both xy and xz direction. The sections were exported as TIFF files, and analysed using the signal area function in COMSTAT (see above). The relative area of probe signal to SYTO9 signal was calculated and used to determine the corresponding probe bio volume from the total bio volume. Finally, the probe bio volume was divided by a specific cell volume (see below) to estimate the cell numbers. To measure the mean AOB cell size, highly magnified zstacks (60 objective and 4. digital zoom, optical resolution $d=0.20 \mu \mathrm{m}$ ) were collected from clusters of AOB targeted with the probes Nso190 and 6a192. The images were exported as series of TIFF files and analysed using the measure tool in Adobe Photoshop 7.0. By comparing each section with the adjoining sections, only cells that appeared to be viewed from the side were measured. For each probe a mean cell volume was calculated from the length and width of 100 distinct cells for each probe, randomly picked from several different aggregates in both processes.

\subsection{DNA Extraction from AOB Cultures and Activated Sludge}

Liquid, pure cultures of AOB were grown at room temperature in the dark in an ammonium-containing medium ( $\mathrm{pH} 7.5$ ) as described by MacDonald and Spokes (1980) and Donaldson and Henderson (1989). Cells from 
Nitrosomonas europaea and Nitrosospira multiformis cultures were harvested by centrifugation and DNA extractions were performed using a QIA amp Tissue Kit according to the protocol supplied by the manufacturer. DNA was extracted from activated sludge with the Fast DNA TM SPIN kit for Soil. The frozen pellet from $10 \mathrm{ml}$ activated sludge was suspended in $2.93 \mathrm{ml}$ phosphate buffer from the extraction kit. The suspension was divided in three extraction tubes and DNA was extracted and purified according to the manufacturer's instructions. The DNA concentration was determined with PicoGreen_ (Molecular Probes) on a FLUO star spectrometer.

\subsection{PCR Amplification of AOB 16S rRNA Genes and DGGE Analysis}

A nested PCR approach was used to amplify partial 16S rDNA of AOB. In the first PCR, the primers EC9-26 (GAGTTTGATCMTGGCTCA, modified from 'fD2' by Weisburg et al. 1991) and P13B (GTGTACTAGG CCCGGGAACGTATTC, Tiveljung et al. 1995) were employed to amplify a 1.4-kbp fragment of bacterial 16S rDNA. The PCR was performed on a PTC-100TM thermal cycler under the following conditions: 2 min at $94^{\circ} \mathrm{C}$ followed by 30 cycles of $30 \mathrm{~s}$ at $94^{\circ} \mathrm{C}, 30 \mathrm{~s}$ at $45^{\circ} \mathrm{C}$, $1 \mathrm{~min}$ at $72^{\circ} \mathrm{C}$, and a final extension of $10 \mathrm{~min}$ at $72^{\circ} \mathrm{C}$. PCR amplification of the fragments was carried out in 25ll reactions in thin-walled Eppendorf tubes containing 1050 ng template DNA, $1.25 \mathrm{U}$ Taq polymerase with the manufacturer's reaction buffer at $1.5 \mathrm{mmol}$ l) $1 \mathrm{MgCl}_{2}, 50$ lmol l) 1 of each primer, and $200 \mathrm{lmol}$ l) 1 of each dNTP. A 50 -fold dilution of the amplicons was used as templates in the second PCR for amplification of partial rDNA sequences from $\mathrm{AOB}$ belonging to the b-subdivision of
Proteobacteria with the primers CTO189fA/B-GC and CTO189fC-GC

(CGCCGCGCGGCGGGCGGGGCGGGGGCACGGGG GGAGRAAAGCAGGGGATCG and CGCCCGCCGCGCGGCGGGCGGGGCGGGGGCACG GGGGGAGGAAAGTAGGGGATCG) and CTO654r (CTAGCYTTGTAGTTTCAAACGC) developed by Kowalchuk et al. (1997). The reaction mixture was composed as stated above. The second PCR was run with an initial denaturation of the template DNA at $94^{\circ} \mathrm{C}$ for 3 min followed by 35 cycles of $30 \mathrm{~s}$ at $94^{\circ} \mathrm{C}, 30 \mathrm{~s}$ at $57^{\circ} \mathrm{C}$, and $45 \mathrm{~s}$ at $72^{\circ} \mathrm{C}$. The reaction was completed after $10 \mathrm{~min}$ at $72^{\circ} \mathrm{C}$. All primers were purchased from Invitrogen $\mathrm{AB}$. The partial 16S rDNA amplified from samples taken in weeks $5,6,8,10,14,15,22,24$, and 26 was analysed by DGGE on a DCode universal mutation detection system. $160 \cdot 160 \mathrm{~mm}$ Polyacrylamide gels were cast using a 1709042 Model 475 Gradient Delivery System. The gels consisted of $7 \%$ acrylamide : bisacrylamide (37.5: 1 ) and a $30-60 \%$ denaturant gradient $(100 \%$ denaturant was defined as $7 \mathrm{~mol} \mathrm{l}$ ) 1 urea and $40 \%$ formamide). A quantity of $15 \mathrm{ll}$ of the respective PCR product was loaded on the gels, which were run at $60^{\circ} \mathrm{C}$ and $130 \mathrm{~V}$ for $13 \mathrm{~h}$ in $1 \mathrm{X}$ TAE (40 mmol l)1 Tris-HCl, $20 \mathrm{mmol} \mathrm{l}$ )1 acetic acid, 1 mmol l)1 EDTA, pH 8Æ3). The DNA fragments were visualized with UV translumination after ethidium bromide staining and the visible bands were cut out from the gels, placed in $160 \mathrm{ll}$ of distilled water, and stored at) $70^{\circ} \mathrm{C}$ until sequencing.

\subsection{Nucleotide Sequencing and Sequence Analysis}

Table 2. FISH probes targeting 16s rRna and the hybridization conditions that were used in this study

\begin{tabular}{|c|c|c|c|c|c|c|}
\hline Probe & Sequence (5’-3’) & $\begin{array}{l}\text { Target } \\
\text { site* }\end{array}$ & Specificity & $\begin{array}{c}\text { Formamide } \\
(\%) \dagger\end{array}$ & $\begin{array}{c}\mathrm{NaCl} \\
\left(\mathrm{mmol} \mathrm{l}^{-1}\right) \ddagger\end{array}$ & Reference \\
\hline Nso190 & CGATCCCTGCTTTCTCC & $189-207$ & Ammonia-oxidizing beta-prpteobacteria & 259 & 159 & Mobarry et al. 1996 \\
\hline Nsol225 & CGCCITTGTATTACGTGTGA§ & $\begin{array}{c}1225- \\
1244\end{array}$ & Ammonia-oxidizing beta-prpteobacteria & 35 & 80 & Mobarry et al. $1996 \S$ \\
\hline Nsv443 & CCGTACCGTTTCGTTCCG & $444-162$ & Nitrosospira spp. & 30 & 112 & Mobarry et al. 1996 \\
\hline Nsm156 & TATTAGCACATCTTTCGAT & $156-174$ & $\begin{array}{l}\text { Various Nitrosomonas spp. and } \\
\text { Nitrosococcus mobilis }\end{array}$ & 5 & 636 & Mobarry et al. 1996 \\
\hline NEU** & ССССTCTGCTGCACTCTA & $653-670$ & $\begin{array}{l}\text { Halophilic and halotolerant members of } \\
\text { the genus Nitrosomonas }\end{array}$ & 40 & 56 & Wagner et al. 1995 \\
\hline NOLI191** & CGATCCCCCVCTTTCCTC & $191-208$ & $\begin{array}{c}\text { Various members of the Nitrosomonas } \\
\text { oligotropha lineage }\end{array}$ & 30 & 112 & Gieseke et al. 2001 \\
\hline Nmo218 & CGGCCGCTCAAAAGCAT & $218-235$ & Nitrosomonas oligotropha lineage & 35 & 80 & Gieseke et al. 2001 \\
\hline $\begin{array}{l}\text { Cluster } \\
6 a 192 * *\end{array}$ & CTTTCGATCСССТАСТTTCС & $192-211$ & Nitrosomonas oligotropha lineage & 35 & 80 & Adamczyck et al. 2003 \\
\hline NmII & TTAAGACACGTTCCGATGTA & $120-139$ & Nitrosomonas communis lineage & 25 & 159 & $\begin{array}{l}\text { Pommerening-Röser et } \\
\text { al. } 1996\end{array}$ \\
\hline NmIV & TCTCACСТCTCAGCGAGCT & $\begin{array}{c}1004- \\
1023\end{array}$ & Nitrosomonas cryotolerans lineage & 35 & 80 & $\begin{array}{c}\text { Pommerening-Röser et } \\
\text { al. } 1996\end{array}$ \\
\hline $\mathrm{NmV}$ & TCCTCAGACTACGCGG & 174-191 & Nitrosomonas mobilis lineage & 35 & 80 & $\begin{array}{l}\text { Pommerening-Röser et } \\
\text { al. } 1996\end{array}$ \\
\hline Nsc1472†† & ACCCCAGTCATGACCCCC & $\begin{array}{l}1472- \\
14 S 9\end{array}$ & Nitrosomonas europaea & 50 & 28 & Juretschko et al. 1998 \\
\hline Ntspa712杖 & CGCCTTCGCCACCGGCCTTCC & $712-732$ & Phylum Nitrospira & 35 & 80 & Daims et al. 2000 \\
\hline
\end{tabular}

*Escherichia coli 16S rRNA position (Brosius et al. 1981),

†Percentage of formamide in the hybridization buffer.

\$Concentration of sodium chloride in the washing buffer

§Wrong sequence is given in the origunal reference, erratum in Appl Environ Microbio (1997) 63, 815.

9Formamide concentration according to Konuma et al. (2001)

**Used together with an equimolar amount of unlabelled competitor oligonucleotide as indicated in the reference

††Referred to as S-*-Nse-1472-a-A-18 in the reference.

\#+Referred to as S-*-Ntspa-0712-a-A-21 in the reference.

To elute the DNA from the polyacrylamide gels the samples were thawed for $1 \mathrm{~h}$ at room temperature, frozen

at) $70^{\circ} \mathrm{C}$ for $1 \mathrm{~h}$, and then thawed again at $8^{\circ} \mathrm{C}$ for $12 \mathrm{~h}$. The eluted DNA was used as template in a PCR- 
amplification with the CTO-primers without GC-clamp at

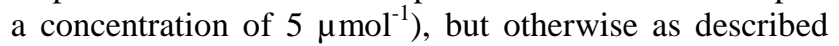
above. Prior to sequencing, $45 \mathrm{ll}$ of PCR product was purified with a MicroSpin S-400 HR column (Amersham Pharmacia Biotech, Uppsala, Sweden). The DNA fragments were sequenced in $11 \mathrm{ll}$ reactions by using the DYEnamic ET Terminator Cycle Sequencing kit. The CTO primers without GC-clamp were also used as sequencing primers and the products were separated on an ABI PRISM 377 automated sequencer. Nucleotide sequences were aligned using the CLUSTAL W software (http://www.ebi.ac.uk/clustalw/) and the sequences were compared with the GenBank database using BLASTn (http://www.ncbi.nlm.nih.gov/BLAST/). A phylogenetic analysis was performed with the software TREECON (Van de Peer and De Wachter 1994) applying Jukes and Cantor correction and the neighbour-joining method (Saitou and Nei 1987) in the program.

\subsection{Statistical Analysis}

All quantitative data from the two processes were compared statistically using paired t-tests at a confidence level of $95 \%$.

\section{Results}

\subsection{Functional Performance of Activated Sludge Processes}

There was no difference regarding process performance and nitrogen removal in the two different systems (Table 1). During the period both had nearly $80 \%$ nitrogen removal efficiency and the average effluent $\mathrm{NH}_{4}-\mathrm{N}$ and $\mathrm{NO}_{3}-\mathrm{N}$ concentration was below 1 and $6 \mathrm{mg} \mathrm{l}^{-1}$ respectively. The potential nitrification, indicating the maximum capacity of the process, exceeded the actual rates on all sampling occasions in both systems (Figure 1). Both the actual and potential nitrification rates were significantly higher in the short SRT process than in the long SRT process, although the potential rates did not differ as much between the two process configurations as the actual rates. The difference between the processes in potential rate was more pronounced at the end of the experimental period while the difference in actual rates was already noticeable 1 week after the suspended solids started to accumulate.

\subsection{Composition of AOB Communities as Determined by DGGE}

The PCR amplification with the AOB-specific CTO primers did not consistently yield detectable PCR products. It was therefore necessary to undertake a nested PCR approach with the universal bacterial primers followed by the CTO primers. The amplified partial 16S rDNA sequences were then analysed by DGGE and sequenced to determine the composition of the ammonia oxidizer communities in the two different activated sludge processes. There was no difference in the community composition determined by DGGE banding pattern either between the two operational strategies or during the experimental period (Figure 2 and data not shown). Moreover, the triplicate DNA extractions from every sample resulted in the same patterns. In Figure 2, DGGE patterns of representative samples from weeks 14 and 22 are shown. A pattern of one distinct and one less distinct band was detected in all samples and this pattern was reproducible. In the sludge sample collected during week 8 from the process with short SRT another weak band was present in all three replicates, located below the dominant band (not shown). None of the bands in the samples comigrated with the Nitrosomonas sp. and Nitrosospira sp. reference strains. Unambiguous identification of ammonia oxidizer populations cannot be based on migration patterns alone. The identity of the two visible bands from levels A and B, as well as the band appearing in week 8, was therefore confirmed by direct sequencing of the excised and re-amplified 16S rDNA DGGE bands. Four bands from each level were randomly picked from each process and sequenced and they all contained the same sequence. The phylogenetic analysis showed that the sequence, denoted DGGE band B, related to cluster 6a of the genus Nitrosomonas. Within this cluster the sequence had the closest relationship to Nitrosomonas oligotrophalike strains

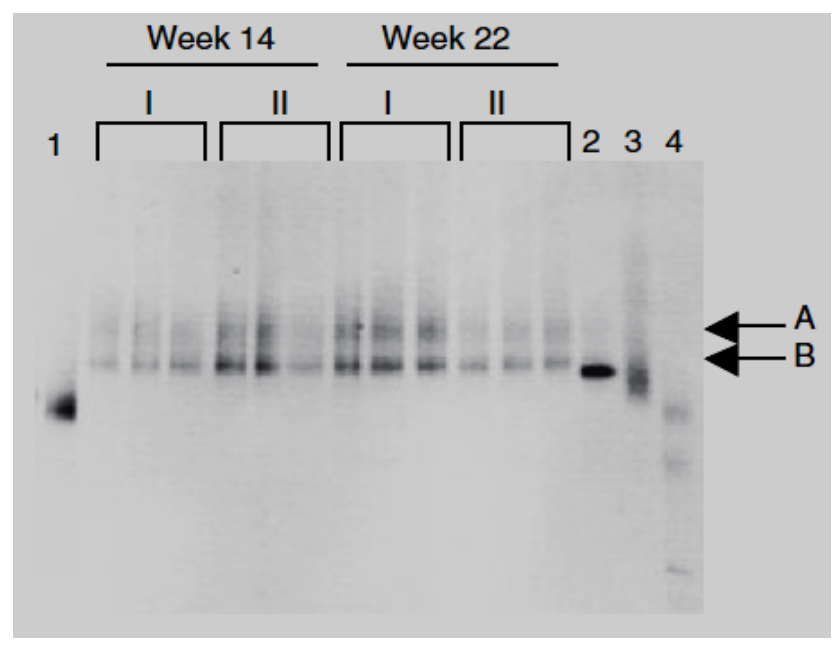

Figure 2. Negative DGGE image of AOB in samples from the process with (I) long solids retention time and (II) short solids retention time collected during weeks 14 and 22. Arrows indicate the two possible bands that were visible at levels A and B in all samples. Lanes 1-4 show the positions of the four reference strains: 1, Nitrosornonas europaea NCIMB 11850; 2, Nitrosomonas marina.; 3, Nitrosotnonas eutropha; 4, Nitrosomonas europaea NCIMB 11850/Nitrosospira multiformis NCIMB 11849. The gels were stained with ethidium bromide

\subsection{Composition of AOB Community Determined by FISH Analysis}

Fluorescence in situ hybridization was performed with all probes listed in Table 2. Positive results were obtained with Nso1225, Nso190, Nsm156, Nse1472 and 6a192 in all samples from both processes. Simultaneous hybridization of these probes revealed the existence of two main groups of AOB (Figure 3). Group I was targeted by both Nso1225 and Nso190. The major part of group I, denoted Ia, was also targeted by the probes Nsm156 and Nse1472, showing that they belonged to the Nitrosomonas europaea/Nitrosococcus mobilis lineage. The remaining bacteria of group I were only targeted by Nso1225 and Nso190, which indicated the presence of another unidentified, although very small, population of AOB (Ib) within this group. Group II consisted only of bacteria 
belonging to the Nitrosomonas oligotropha lineage within cluster $6 \mathrm{a}$, as shown by the positive signal from probe 6a192. The latter is consistent with the findings from the DGGE analysis. The bacteria of this group did not hybridize at all with Nso190, although they target overlapping regions. Most of the bacteria within group II were targeted only by probe 6a192 (IIa), but within group II there was also another smaller population (IIb) targeted both by 6a192 and Nso1225 (Figure 3). To conclude, all members of group I could be identified by a single probe (Nso190) and all members of group II by probe 6a192. Group I was significantly more abundant than group II in the samples from weeks 6,8 and 26 in the process with short SRT, and in the samples from weeks 14 and 26 in the process with long SRT (Figure 4). No significant difference was found between the two groups in all other samples but there was a tendency for group I to be the most numerous in all samples. Group I constituted between 1.5 and $3.6 \%$ of the total amount of bacteria. Group II, was less abundant and constituted $0.3-1.9 \%$ of the total amount of bacteria in both processes. No signal was obtained with any of the other probes, which includes both Nmo218 and NOLI191 that target bacteria within the Nitrosomonas oligotropha lineage and Nsv443 that target AOB of the genus Nitrosospira. To get a rough estimate of the complete nitrifying population, a few samples from both processes were also hybridized with the probe Ntspa712, targeting nitrite-oxidizing bacteria of the phylum Nitrospira. The amount of signal from this probe was $5-7 \%$ of the total amount of bacteria in all samples and no difference between the two processes was observed (data not shown).
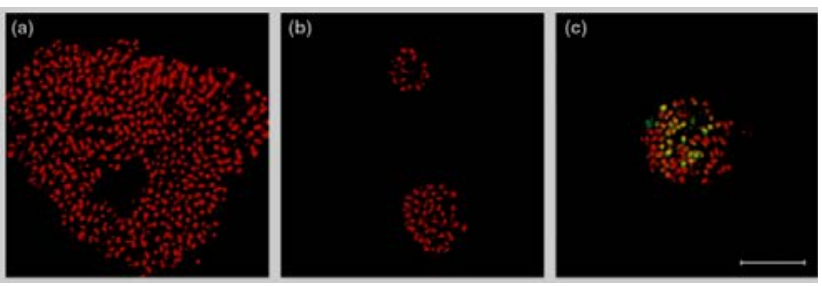

Figure 3. Confocal laser scanning micographs showing three of the AOB populations detected by FISH in activated sludge samples from the process with long solids retention time. Scale bar $=10 \mu \mathrm{m}$. (a) Large aggregate of the most abundant AOB population (Ia), belonging to the Nitrosomonas europaea/Nitrosococcus mobilis lineage, hybridized with Nso190. (b) Two aggregates of the dominating Nitrosomonas oligotropha-like population that was detected only by 6a192. (c) An aggregate containing two Nitrosomonas oligotripha-like populations. The most abundant population (IIa) apperas as red (targeted by 6a192), and the less abundant population (IIb) as yellow (targeted by 6a192 and Nso1225). The latter appeared exclusively in mixed aggregates

\subsection{Morphology and Size of AOB Cells and Aggregates}

A small difference in shape was noted between the two AOB groups detected by FISH. Both groups consisted of short rod-shaped bacteria of roughly the same size, but the cells of group I was longer and more slender than the cells of group II. The size and morphology of all observed AOB cells were in accordance with that reported in the literature for isolated AOB cells of the genus Nitrosomonas and especially Nitrosomonas europaea, Nitrosomonas oligotropha and Nitrosomonas ureae (Koops et al. 2003). Almost all of the AOB cells were associated in aggregates. No difference in shape or cell size was noted between the two operational strategies, but the cells of group I generally appeared in larger aggregates (mean size 15-30 lm; maximum size >100 lm; Figure 3a) than the cells of group II (mean size 5-10 lm; maximum size 35-40 lm; Figure 3b,c). The less abundant population of group II (IIb) always appeared in mixed aggregates together with the dominant population IIa, whereas the latter also appeared in separate aggregates (Figure 3). The two populations of group I exclusively appeared in separate aggregates.

\subsection{Size of Ammonia-oxidizing Community and total Bacterial Biomass}

As mentioned above, the most universal AOB probe Nso1225 did not target all AOB in the samples, and could therefore not be used to calculate the total amount of AOB alone. However, the hybridization results showed that all AOB that could be detected always hybridized with either Nso190 (group I) or 6a192 (group II), and that there was no overlap between the two. The total AOB numbers were therefore calculated by adding the hybridization signals from the probes Nso190 and 6a192. The AOB numbers were not significantly different between the two operational strategies during the period, but a significant increase in $\mathrm{AOB}$ numbers from the start to the end of the period could be seen in both operational strategies (Figure 4). In the process operated with long SRT, the amount of group I AOB increased more than twofold from weeks 6 to 8 , and then again from weeks 22 to 26 resulting in a population size five times larger than during week 6 . Group II showed no increase during the period, with the exception of the sample from week 22, which was significantly higher than in week 6. In the short SRT process, the amount of group I AOB initially increased in a similar manner, with a twofold increase from weeks 6 to 14 , but no increase could be seen at the end of the period. In contrast, a significant increase of group II could be seen, which increased four times between weeks 8 and 14. The amount of bacterial biomass, which was calculated as the volume of SYTO9-positive cells per gram MLVSS, did not differ between the two operation modes at any time (Figure 4). However, both strategies showed a significant two- to threefold increase of biomass in the beginning of the period, from weeks 6 to 8 . Another significant increase followed from weeks 8 to 22, resulting in a threefold total increase of biomass from weeks 6 to 26 in the process with long SRT. In the one with short SRT, the highest biomass value was reached between weeks 14 and 22, followed by a significant decrease of the biomass by week 26. This resulted in a less than twofold total increase of biomass from weeks 6 to 26 .

\section{Discussion}

\subsection{Nitrification Activity and Abundance of AOB}

Both modes of operation, i.e. long or short SRT, resulted in efficient nitrogen removal processes with approximately $80 \%$ nitrogen removal and low $\mathrm{NH}_{4}-\mathrm{N}$ discharges. As expected, the process with short SRT had a 
more biologically active sludge as was seen from the nitrification rates expressed on an MLVSS basis. The difference in the actual rates, based on nitrogen mass balances, was immediate when the operational mode in one of the trains was shifted to increase the SRT at the start of the experiment. The actual rate in the short SRT process gradually increased over the period while the other process fluctuated at a low and constant rate (Figure 1 ). The ratio between the actual nitrification rates of the two processes was $0 Æ 69$, which is the same as the ratio between their SRTs $(10.7 / 15.6=0.69)$. This seems to confirm the relation between the SRT and nitrification activity. The lower DO levels in the process with long SRT may have suppressed the activity and the higher organic matter content could have resulted in nitrifying bacteria competing with heterotrophs for ammonia (Hanaki et al. 1990). Nevertheless, the ammonium disappeared efficiently in both processes and the difference in DO probably did not affect the total nitrification in the plant. The potential rates, which were not affected by the environmental conditions at the time of sampling, demonstrate the maximum capacity of the AOB communities in the treatment plant. The potential rate was only slightly higher in the process run with a short SRT than in the one with a long SRT but a large difference between the operational modes was observed during the last 5-6 weeks (Figure 1). We interpret the different potential rates that were seen at the end of the experimental period as an indication of physiological differences between the AOB ommunities in the two processes. As our data showed that that the AOB numbers were similar in the two processes on all sampling occasions (Figure 4) and that no detectable community shifts had occurred, we suggest that the effect of a longer SRT on the activity mainly was because of physiological alterations of the original AOB populations. The AOB numbers and the total bacterial biomass increased in the two systems during the experimental period. This was probably an effect of the temperature increase during the season. FISH results showed that the ammonia oxidizers constituted $3-5 \%$ of the total biomass in the two processes. The proportion of AOB increased to some extent in both of them, but it was only statistically significant in the long SRT process. This was probably also a temperature effect. The proportion of nitrifying bacteria, which include both AOB and nitrite-oxidizing bacteria, in activated sludge is assumed to be $2-5 \%$ (Randall et al. 1992) and the latest 'Activated Sludge Model' estimated the nitrifying bacteria to be $2-3 \%$ of the total biomass (Koch et al. 2001). Taking into account the roughly estimated value of $5-7 \%$ nitriteoxidizing bacteria in this study, our results suggest a somewhat higher proportion of nitrifying bacteria (10\%). However, AOB values ranging from 0Æ0033\% (Dionisi et al. 2002a) to $15 \%$ (Wagner et al. 1995) have been reported, which may reflect differences in the relative ammonia oxidizer community size between the treatment plants. As the increased activity in the process with short SRT, as compared with the one with long SRT, could not be explained by a difference in AOB numbers, the specific activity (k0) was calculated using the actual and potential nitrification rates presented in Figure 1 (Table 3). The results show that in general the short SRT process had a higher specific activity, except for in week 14. The specific activity was highest in the beginning of the experiment in both processes, due to the low AOB numbers, and eventually decreased. However, as the AOB numbers have a high standard deviation, the differences in specific activity must be regarded as tendencies only. Moreover, the k0 estimations may be biased by FISH detection of dormant AOB cells, as cells can retain high ribosome content during periods of low physiological activity (Fla“rdh et al. 1992; Wagner et al. 1995; Morgenroth et al. 2000). The specific activity of pure cultures of AOB is in the range of 1.2-23 fmol cell ${ }^{-1} \mathrm{~h}^{-1}$ and species belonging to the genus Nitrosomonas have higher k0-values than those within the genus Nitrosospira (Belser 1979; Laanbroek and Gerards 1993). Daims et al. (2001) determined a slightly lower in situ activity than we did when FISH was used for AOB enumeration and Wagner et al. (1995) reported values as low as $0.22 \mathrm{fmol}$ $\mathrm{N}$ cell ${ }^{-1} \mathrm{~h}^{-1}$ with the same method. Harms et al. (2003), who used a real-time PCR TaqMan assay to enumerate AOB, reported a mean $\mathrm{k} 0$ value of $7.7 \mathrm{fmol} \mathrm{N}^{\mathrm{N}} \mathrm{cell}^{-1} \mathrm{~h}^{-1}$ and calculations based on enumeration with CPCR of Nitrosomonas oligotropha-like AOB were in the range of 3.5-56 fmol cell $\mathrm{f}^{-1}$ in the same samples. In activated sludge processes the $\mathrm{k} 0$ values are subject to fluctuating environmental conditions and can therefore vary widely. Only a few studies on AOB enumeration over longer periods in activated sludge systems have been reported and all of these were performed with PCR-based methods (Dionisi et al. 2002a,b; Harms et al. 2003). Traditionally, FISH has mostly been used for relative measurements of bacterial populations in biofilms or activated sludge samples, as the complex distribution of the cells in these environments makes the cells hard to quantify. One way to circumvent this problem is to spike the samples with a known amount of Escherichia coli cells, and use the signal from these cells to calculate the absolute numbers of other cells in the sample (Daims et al. 2001). However, this method did not work in the present study, as the E. coli cells would not distribute evenly in the samples due to the large, impenetrable sludge flocs. Instead we developed another way to quantify the FISH signal based on measurements of biovolume, relative area and specific cell volumes. The numbers of AOB obtained with this method (Figure 3) were within the reasonable range that has previously been determined in activated sludge processes (Wagner et al. 1995; Kowalchuk et al. 1999; Daims et al. 2001; Dionisi et al. 2002a; Harms et al. 2003). We used a large set of probes to target the AOB population (Table 2). Generally, the probe Nso1225 is considered to be the most universal, targeting almost all beta-proteobacterial AOB. Nevertheless, in this study we were not able to detect all AOB present with Nso1225. In fact, none of the probes we used initially could detect any bacteria belonging to the Nitrosomonas oligotropha lineage, which had been identified by DGGE. No signal was obtained from the probes NOLI191 and Nmo218, both targeting bacteria within this lineage. However, after the recent publication of the probe 6a192 (Adamczyck et al. 2003), the lost population was finally detected. Co-staining of the samples with both Nso1225 and 6a192 showed that Nso1225 was able to detect a very small population of bacteria within the Nitrosomonas oligotropha lineage (Figure 3). This result strongly emphasizes the need for further development of FISH probes for AOB, as the most commonly used ones Nso190 and Nso1225 in some cases 
clearly underestimate the total number of AOB, thereby giving a biased picture of the microbial ecology of the activated sludge systems.

\begin{tabular}{|c|c|c|}
\hline \multirow[t]{2}{*}{ Week } & $\begin{array}{l}\text { Actual specific activity* } \\
\text { (fmol N cell-1 h-1) }\end{array}$ & $\begin{array}{l}\text { Potential specific activity } \dagger \\
\text { (fmol N cell-1 h-1) }\end{array}$ \\
\hline & in & I II \\
\hline 6 & 1315 & 3134 \\
\hline 8 & 59 & 1418 \\
\hline 14 & 74 & 179 \\
\hline 22 & 57 & 1415 \\
\hline 26 & 35 & 58 \\
\hline
\end{tabular}

*Actual nitrification rates from nitrogen mass balances

†Potential nitrification rates from batch experiments.

\subsection{AOB Community Analysis}

The community analysis with both the in situ hybridization and the PCR-dependent approach demonstrated that populations related to Nitrosomonas were responsible for ammonia oxidation at the Henriksdal WWTP and that Nitrosospira-like AOB were not detected. All DGGE analyses of PCR-amplified 16S rDNA from AOB resulted in one AOB sequence. The phylogenetic analysis showed that it falls into cluster $6 \mathrm{a}$ where the Nitrosomonas oligotropha and Nitrosomonas ureae lineages are found and that it is closely related to Nitrosomonas oligotropha Nm 45 (Koops et al. 1991). The nearest neighbour to the 410 bp sequence was an uncultured Nitrosomonas sp. (Clone 26Ft, GenBank acc. no. AF527015) that was recently found in a wastewater treatment reactor (Rowan et al. 2003). The population detected by DGGE was also detected by the FISH-probe 6a192, which targets bacteria within the Nitrosomonas oligotropha lineage. As a small part of the 6a192-positive cells also hybridized with Nso1225, there were probably at least two different populations present within the Nitrosomonas oligotropha lineage (IIa and IIb). In addition, another abundant AOB group, denoted Ia was identified by FISH with the probes Nse1472 and Nsm156, which suggests that at least one AOB population belonging to the Nitrosomonas europaea/Nitrosococcus mobilis lineage (cluster 7) was present. This population could not be detected by DGGE. Finally, the FISH results detected the presence of other unidentified members of the genus Nitrosomonas, here referred to as Ib, in the sludge samples, as parts of the community that hybridized to the probes Nso190 and Nso1225 did not hybridize with any of the more specific probes. The CTO primers that were used for PCR are not universal for all beta-proteobacterial AOB and they have mismatches with some sequences in cluster 7, which holds the Nitrosomonas europaea/Nitrosococcus mobilis lineage identified by FISH in this study (Purkhold et al. 2000). This could explain the differences in the results from FISH and DGGE analysis. In addition, the FISH probes NOLI191 and Nmo218 that target the Nitrosomonas oligotropha lineage have mismatches with some of the isolated bacteria from cluster 6a (Koops et al. 2003). This is probably the reason why these probes could not detect the populations that were found by the 6a192 probe and by DGGE analysis. The finding that members of the genus Nitrosomonas dominated the activated sludge processes was not surprising as they are known to thrive in nitrogen-rich environments such as activated sludge processes. Our results are in agreement with the findings of Dionisi et al. (2002a) who detected nothing but members of Nitrosomonas, with a dominance of Nitrosomonas oligotropha, in a 1-year study of a municipal WWTP. Nevertheless, almost all recognized lineages of beta-proteobacterial $\mathrm{AOB}$ can be found in WWTPs and from surveys in wastewater treatment processes it has been suggested that different plants support different populations. Members of the Nitrosomonas europaea/Nitrosococcus mobilis and the Nitrosomonas marina clusters have been most frequently detected (Purkhold et al. 2000; Wagner et al. 2002). These more recently published results are all in agreement with older findings (e.g. Mobarry et al. 1996; Wagner et al. 1996). The relatively long SRT that both processes were operated with in this study most likely selected for two AOB populations that dominated in both processes, although two others were found in low abundance. Despite the different environmental conditions for the $\mathrm{AOB}$ in the two processes, the total selective pressure in the two experimental trains was not strong enough to induce a population shift. The number of different populations can differ significantly between WWTPs and sometimes plants even harbor AOB monocultures (Juretschko et al. 1998; Purkhold et al. 2000). WWTPs with long SRTs, such as in this study, have been reported to have less variable biomass characteristics (Henze et al. 2002). Daims et al. (2001) suggested that the level of AOB diversity relates to the operational stability of the process and there have been indications that plants with a low diversity of a given functional group are more prone to process failure than plants showing a higher diversity of the same bacterial group (Wagner et al. 2002). A selection for AOB populations that are more robust to environmental disturbances can also reduce the vulnerability of the plant, and this would be advantageous for process control. However, diversity determined from 16S rRNA gene analysis does not always reflect true genetic diversity. Hitherto unidentified AOB may be present in the system although they are not detected and other genes, which affect AOB properties and ecosystem functioning, can probably differ between closely related AOB appearing identical in partial 16S rRNA sequences. Jaspers and Overmann (2004) recently showed that identical 16SrRNA gene sequences were found in Brevundimonas alba with highly divergent genomes and ecophysiologies. A better understanding of the links between the true genetic diversity of the functionally important AOB and the stability of the process they carry out is necessary to be able to protect the plants from process deterioration.

\section{Concluding Remarks}

The MLSS concentration and SRT affected the nitrification activity but not the numbers or the community composition of AOB. Hence, long-term application of a specific operational strategy may result in a change in the physiological state of the bacterial populations, without inducing a change in community structure. Our results support the concept of sludge population optimization, which Yuan and Blackall (2002) argued should be an aim for the design and operation of a 
treatment plant. The FISH results in this study clearly indicate that neither of the commonly used probes Nso190 and Nso1225 can be used for correct enumeration of total AOB numbers in activated sludge when certain populations of the Nitrosomonas oligotropha lineage are present in the process. Reliable numbers of AOB are important for monitoring and modelling of activated sludge processes. Therefore, more universal AOB FISH probes and other quantitative methods must be further developed.
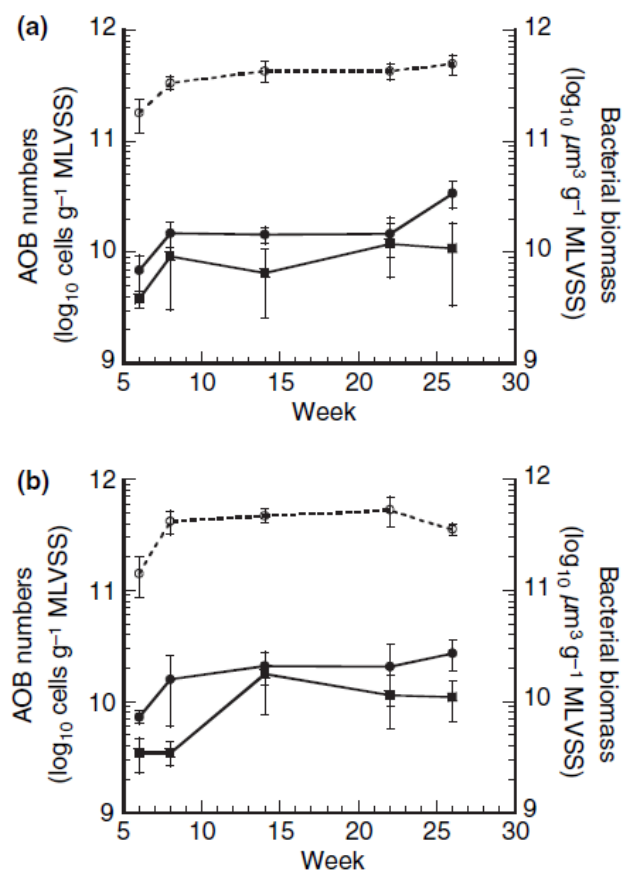

Figure 4. Total bacterial biomass stained by SYTO9 (०) and number of group I (•) and group II (ロ) AOB cells determined with probes Nsol9O and Cluster 6a192 respectively using FISH analysis. Krror bars indicate the standard deviation. Process with (a) long and (b) short solids retention time

\section{References}

[1] Adamczyck, J., Hesselsoe, M., Iversen, N., Horn, M., Lehner, A. Nielsen, P.H., Schloter, M., Roslev, P. et al. (2003) The isotope array, a new tool that employs substrate-mediated labeling of rRNA for determination of microbial community structure and function. Appl Environ Microbiol 69, 6875-6887.

[2] Anon (1993) Avprøvning av screeningmetoder for nitrifikationshæmning. Hørsholm, Denmark: Vandkvalitetsinstitutet.

[3] Belser, L.W. (1979) Population ecology of nitrifying bacteria. Annu Rev Microbiol 33, 309-333.

[4] Blackburne, R., Yuan, Z.G., Keller, J., 2008. Partial nitrification to nitrite using low dissolved oxygen concentration as the main selection factor. Biodegradation 19 (2), 303-312.

[5] Daims, H., Nilesen, P.H., Nielsen, J.L., Juretschko, S. and Wagner, M. (2000) Novel Nitrospira-like bacteria as dominant nitrite oxidizers in biofilms from wastewater treatment plants: diversity and in situ physiology. Water Sci Technol 41, 85-90.

[6] Daims, H., Ramsing, N.B., Schleifer, K.-H. and Wagner, M. (2001) Cultivation-independent, semiautomatic determination of absolute bacterial cell numbers in environmental samples by fluorescence in situ hybridisation. Appl Environ Microbiol 67, 5810-5818.

[7] Dionisi, H.M., Layton, A.C., Harms, G., Gregory, I.R., Robinson, K.G. and Sayler, G.S. (2002a) Quantification of Nitrosomonas oligotropha-like ammonia-oxidizing bacteria and Nitrospira spp. from full-scale wastewater treatment plants by competitive PCR. Appl Environ Microbiol 68, 245-253.
[8] Dionisi, H.M., Layton, A.C., Robinson, K.G., Brown, J.R. Gregory, I.R., Parl, J.J. and Saylor, G.S. (2002b) Quantification of Nitrosomonas oligotropha and Nitrospira spp. using competitive polymerase chain reaction in bench-scale wastewater treatment reactors operating at different solids retention times. Water Environ Res 74, 462-469.

[9] Donaldson, J.M. and Henderson, G.S. (1989) A dilute medium to determine population size $\mathrm{f}$ ammonium oxidizers in soil. Soil Sci Soc Am J 53, 1608-1611.

[10] Dworking, M., Falkow, S., Rosenberg, E., Schleifer, K.-H. and Stackebrandt, E. New York: Online, Springer-Verlag, http://link.springer-ny.com/link/service/books/10125/

[11] Fla“rdh, K., Cohen, P. and Kjelleberg, S. (1992) Ribosomes exist in large excess over the apparent demand for protein synthesis during carbon starvation in marine Vibrio sp. strain CCUG 15956. J Bacteriol 174, 6780-6788.

[12] Gieseke, A., Purkhold, U., Wagner, M., Amann, R. and Schramm, A. (2001) Community structure and activity dynamics of nitrifying bacteria in a phosphate-removing biofilm. Appl Environ Microbiol 67, 1351-1362.

[13] Guo, J.H., Peng, Y.Z., Wang, S.Y., Zheng, Y.N., Huang, H.J., Wang, Z.W., 2009. Longterm effect of dissolved oxygen on partial nitrification performance and microbial community structure. Bioresour. Technol. 100 (11), 2796-2802.

[14] Hanaki, K., Wanatwin, C. and Ohgaki, S. (1990) Effects of the activity of heterotrophs on nitrification in a suspended-growth reactor. Water Res 24, 289-296.

[15] Harms, G., Layton, A.C., Dionisi, H.M., Gregory, I.R., Garrett, V.M, Hawkins, S.A., Robinson, K.G. and Sayler, G.S. (2003) Real-time PCR quantification of nitrifying bacteria in a municipal wastewater treatment plan. Environ Sci Technol 37, 343-351.

[16] He, Y.L., Tao, W.D., Wang, Z.Y., Shayya, W., 2012. Effects of $\mathrm{pH}$ and seasonal temperature variation on simultaneous partial nitrification and anammox in free-water surface wetlands. J. Environ. Manage. 110, 103-109.

[17] Hellinga, C., Schellen, A.A.J.C., Mulder, J.W., Loosdrecht, M.C.M., Heijnen, J.J., 1998. The SHARON process: an innovative method for nitrogen removal from ammonium-rich wastewater. Water Sci. Technol. 37 (9), 135-142.

[18] Henze, M., Aspegren, H., Jansen, J.C., Nielsen, P.H. and Lee, N. (2002) Effects of solids retention time and wastewater characteristics on biological phosphorus removal. Water Sci Technol 45, 137-144.

[19] Heydorn, A., Nielsen, A.T., Hentzer, M., Sternberg, C., Givskov, M., Ersboll, B.K. and Molin, S. (2000) Quantification of biofilm structures by the novel computer program COMSTAT. Microbiology 146, 2395-2407.

[20] Jaspers, E. and Overmann, J. (2004) Ecological significance of microdiversity: identical 16S rRNA gene sequences can be found in bacteria with highly divergent genomes and ecophysiologies. Appl Environ Microbiol 70, 4831-4839.

[21] Juretschko, S., Timmermann, G., Schmid, M., Schleifer, K.-H., Pommerening-Ro“ser, A., Koops, H.-P. and Wagner, M. (1998) Combined molecular and conventional analyses of nitrifying bacterium diversity in activated sludge: Nitrosococcus mobilis and Nitrospira-like bacteria as dominant populations. Appl Environ Microbiol 64, 3042-3051.

[22] Koch, G., Ku“hni, M. and Siegrist, H. (2001) Calibration and validation of an ASM3-based steady-state model for activated sludge systems. Part 1. Prediction of nitrogen removal and sludge production. Water Res 35, 2235-2245.

[23] Koops, H.P., Bo“ttcher, B. Mo“ller, U.C. Pommerening-Ro“ser, A. and Stehr, G. (1991) Classification of eight new species of ammoniaoxidizing bacteria: Nitrosomonas communis sp. nov., Nitrosomonas ureae sp. nov., Nitrosomonas aestuarinii sp. nov., Nitrosomonas marina sp. nov., Nitrosomonas nitrosa sp. nov, Nitrosomonas eutropha sp. nov., Nitrosomonas oligotropha sp. nov. and Nitrosomonas halophila sp. nov. J Gen Microbiol 137, 1689-1699.

[24] Koops, H.-P., Purkhold, U., Pommerening-Ro“ser, A., Timmermann, G. and Wagner, M. (2003) The litotrophic ammonia oxidizing bacteria. In: The Prokaryotes, an Evolving Electronic Resource for the Microbiological Community, 3rd edn, release 3Æ13, March 2003 ed.

[25] Kowalchuk, G.A., Stephen, J.R., de Boer, W., Prosser, J.I., Embley, T.M. and Woldendorp, J.W. (1997) Analysis of ammonia-oxidizing bacteria of the $\beta$ subdivision of the class Proteobacteria in coastal sand dunes by denaturing gradient gel 
electrophoresis and sequencing of PCR-amplified 6S ribosomal DNA fragments. Appl Environ Microbiol 63, 1489-1497.

[26] Laanbroek, H.J. and Gerards, S. (1993) Competition for limiting amounts of oxygen between Nitrosomonas europaea and Nitrobacter winogradskyi grown in mixed continuous cultures. Arch Microbiol 159, 453-459.

[27] MacDonald, R.M. and Spokes, J.R. (1980) A selective and diagnostic medium for ammonia oxidising bacteria. FEMS Microbiol Lett 8, 143-145.

[28] Manz, W., Amann, R., Ludwig, W., Wagner, M. and Schleifer, K.H. (1992) Phylogenetic oligodeoxynucleotide probes for the major subclasses of Proteobacteria: problems and solutions. Syst Appl Microbiol 15, 593-600.

[29] Maulin P Shah, Patel KA, Nair SS, Darji AM, Shaktisinh Maharaul. Optimization of Environmental Parameters on Decolorization of Remazol Black B Using Mixed Culture. American Journal of Microbiological Research. 2013 (1), 3, 53-56.

[30] Maulin P Shah, Patel KA, Nair SS, Darji AM, Shaktisinh Maharaul. Microbial Degradation of Azo Dye by Pseudomonas spp. MPS-2 by an Application of Sequential Microaerophilic and Aerobic Process. American Journal of Microbiological Research. 2013 (1), 43, 105-112.

[31] Maulin P Shah, Patel KA, Nair SS, Darji AM. Microbial Decolorization of Methyl Orange Dye by Pseudomonas spp. ETLM. International Journal of Environmental Bioremediation and Biodegradation. 2013 (1), 2, 54-59.

[32] Maulin P Shah, Patel KA, Nair SS, Darji AM. Microbial Degradation and Decolorization of Reactive Orange Dye by Strain of Pseudomonas Spp. International Journal of Environmental Bioremediation and Biodegradation. 2013 (1), 1, 1-5.

[33] Maulin P Shah, Patel KA, Nair SS, Darji AM. An Innovative Approach to Biodegradation of Textile Dye (Remazol Black) by Bacillus spp. International Journal of Environmental Bioremediation and Biodegradation. 2013 (1), 2, 43-48.

[34] Mobarry, B.K., Wagner, M., Urbain, V., Rittman, B.E. and Stahl, D.A. (1996) Phylogenetic probes for analyzing abundance and spatial organization of nitrifying bacteria. Appl Environ Microbiol 62, 2156-2162.

[35] Mobarry, B.K., Wagner, M., Urbain, V., Rittman, B.E. and Stahl, D.A. (1996) Phylogenetic probes for analyzing abundance and spatial organization of nitrifying bacteria. Appl Environ Microbiol 62, 2156-2162.

[36] Morgenroth, E., Obermayer, A., Arnold, E., Bru“ hl, A., Wagner, M. and Wilderer, P.A. (2000) Effect of long-term idle periods on the performance of sequencing batch reactors. Water Sci Technol 41, 105-113

[37] Mosquera-Corral, A., González, F., Campos, J.L., Mendéz, R. 2005. Partial nitrification in a SHARON reactor in the presence of salts and organic carbon compounds. Process Biochem. 40, 31093118.

[38] Park, S., Bae, W., Rittmann, B.E., 2010. Operational boundaries for nitrite accumulation in nitrification based on minimum maximum substrate concentrations that include effects of oxygen limitation, $\mathrm{pH}$, and free ammonia and free nitrous acid inhibition. Environ. Sci. Technol. 44, 335-342.

[39] Pommerening-Ro“ser, A., Rath, G. and Koops, H.-P. (1996) Phylogenetic diversiy within the genus Nitrosomonas. Sys Appl Microbiol 19, 344-351.

[40] Purkhold, U., Pommerening-Ro"ser, A., Juretschko, S., Schmid, M.C., Koops, H.P. and Wagner, M. (2000) Phylogeny of al recognized species of ammonia oxidizers based on comparative 16S rRNA and amoA sequence analysis: implications for molecular diversity surveys. Appl Environ Microbiol 66, 53685382.

[41] Randall, C.W., Barnard, J.L. and Stensel, H.D (1992) Design and Retrofit of Wastewater Treatment Plants for Biological Nutrient Removal. Lancaster, PA: Technomic Publishing Co. Inc.

[42] Rowan, A.K., Snape, J.R., Fearnside, D., Barer, M.R., Curtis, T.P. and Head, I.M. (2003) Composition and diversity of ammoniaoxidizing bacterial communities in wastewater treatment reactors of different design treating identical wastewater. FEMS Microbiol Ecol 43, 195-206.

[43] Saitou, N. and Nei, M. (1987) The neighbor joining method: a new method for constructing phylogenetic trees. Mol Biol Evol 4, 406425.

[44] Sun, H.W., Yang, Q., Dong, G.R., Hou, H.X., Zhang, S.J., Yang, Y.Y., Peng, Y.Z., 2010. Achieving the nitrite pathway using FA inhibition and process control in UASB-SBR system removing nitrogen from landfill leachate. Sci. China Chem. 53 (5), 12101216.

[45] Tao, W.D., He, Y.L., Wang, Z.Y., Smith, R., Shayya, W., Pei, Y.S., 2012. Effects of $\mathrm{pH}$ and temperature on coupling nitritation and anammox in biofilters treating dairy wastewater. Ecol. Eng. 47, 76-82.

[46] Tiveljung, A., Backstro"m, J., Forsum, U. and Monstein, H.-J. (1995) Broad-range PCR amplification and DNA sequence analysis reveals variable motifs in 16S rRNA genes of Mobiluncus species. Acta Pathol Microbiol Immunol Scand 103, 755-763.

[47] Van de Peer, Y. and De Wachter, R. (1994) TREECON for Windows: a software package for the construction and drawing of evolutionary trees for the Microsoft Windows environment. Comput Appl Biosci 10, 569-570.

[48] Wagner, M., Loy, A., Nogueira, R., Purkhold, U., Lee, N. and Daims, H. (2002) Microbial community composition and function in wastewater treatment plants. Antonie Van Leeuwenhoek 81, 665-680.

[49] Wagner, M., Rath, G., Amann, R., Koops, H.-P. and Schleifer, K.H. (1995) In situ identification of ammonia-oxidizing bacteria. Syst Appl Microbiol 18, 251-264.

[50] Wagner, M., Rath, G., Amann, R., Koops, H.-P. and Schleifer, K. H. (1995) In situ identification of ammonia-oxidizing bacteria. Syst Appl Microbiol 18, 251-264.

[51] Wang, F., Liu, Y., Wang, J.H., Zhang, Y.L., Yang, H.Z., 2012. Influence of growth manner on nitrifying bacterial communities and nitrification kinetics in three lab-scale bioreactors. J. Ind. Microbiol. Biotechnol. 39, 595-604.

[52] Weisburg, W.G., Barns, S.M., Pelletier, D.A. and Lane, D.J. (1991) $16 S$ ribosomal DNA amplification for phylogenetic study. J Bacteriol 173, 697-703.

[53] Yapsakli, K., Aliyazicioglu, C., Mertoglu, B., 2011. Identification and quantitative evaluation of nitrogen-converting organisms in a full-scale leachate treatment plant. J. Environ. Manage. 92, 714723

[54] Zeng, W., Li, L., Yang, Y.Y., Wang, S.Y., Peng, Y.Z., 2010. Nitritation and denitritation of domestic wastewater using a continuous anaerobic-anoxic-aerobic (A2O) process at ambient temperatures. Bioresour. Technol. 101, 8074-8082.

[55] Zhu, G.B., Peng, Y.Z., Li, B.K., Guo, J.H., Yang, Q., Wang, S.Y., 2008. Biological removal of nitrogen from wastewater. Rev. Environ. Contam. Toxicol. 192, 159-195. 